\title{
骨盤腹膜炎を契機に診断された遊離卵巣囊腫の一例
}

秋田大学医学部産婦人科

富樫嘉津恵、熊澤由紀代、白澤弘光、久木元詩央香、

尾野夏紀、佐藤 亘、清水 大、寺田幸弘

\section{Diagnosis of an auto-amputated endometrial ovarian cyst based on a clinical presentation of pelvic peritonitis: A case report}

\author{
Kazue Togashi, Yukiyo Kumazawa, Hiromitsu Shirasawa, Shioka Kukimoto \\ Natsuki Ono, Wataru Sato, Dai Shimizu, Yukihiro Terada \\ Department of Obstetrics and Gynecology, Akita University Hospital
}

\begin{abstract}
Introduction: Ovarian auto-amputation is extremely rare and is most commonly attributed to chronic adnexal torsion and subsequent devascularization that precipitate infarction and necrosis. We describe a woman (Jehovah's witness) who presented with an inflamed abdominal cyst, which was diagnosed as an auto-amputated endometrial ovarian cyst, following laparoscopic surgery.

Case presentation: A 45-year-old Jehovah's witness was referred to our hospital with acute abdominal pain. She had complained of dysmenorrhea prior to referral. Laboratory data revealed evidence of severe inflammation (white blood cell count 12400 cells/ $\mu \mathrm{L}$, C-reactive protein $17.4 \mathrm{mg} / \mathrm{dL}$ ).

MRI revealed a cystic pelvic tumor with features of a benign ovarian cyst. She received intravenous antibiotics with resolution of inflammation following this conservative therapy after which we performed laparoscopic surgery for removal of the pelvic mass. Intraoperatively, we performed careful adhesiolysis followed by meticulous exploration of the pelvic cavity. We performed cystectomy and left adnexectomy with insertion of multiple drains into the peritoneal cavity.

Discussion: Based on the laparoscopic and histopathological findings, the patient was diagnosed with chemical panperitonitis associated with a wandering ovarian endometrial cyst.

Conclusion: We report successful but significantly challenging laparoscopic intervention for a wandering ovarian endometrial cyst in a woman with chemical peritonitis.
\end{abstract}

Key words: Acute abdominal pain; Wandering ovarian cyst; Endometriosis

\section{緒言}

遊離卵巣囊腫は稀な疾患であり、術前の画像診 断は困難とされ、手術により最終診断されること が多い。今回我々は、骨盤腹膜炎を契機に診断さ れた遊離卵巣豪胞に対して腹腔鏡下で加療した症 例を経験したので報告する。なお、本症例を報告 するにあたり、十分な説明と個人情報保護に配慮 し、患者本人より同意を得ている。
症例

45歳 G0P0 未婚 BMI 23.9 事務員 エホバ の証人. 既往歴: 高血圧. 内服薬: シルニジピン. 手術歴：なし.アレルギー：なし. 婦人科検診歴： なし。

月経歴 : 初経 12 歳, 未閉経, 月経周期は整, 28 日 型，過多月経あり。月経困難症あり。

生活歴: 飲酒なし, 喫煙なし. 家族歴: 特記なし. 現病歴：月経第 1 日に発熱、急性の右下腹部痛を 


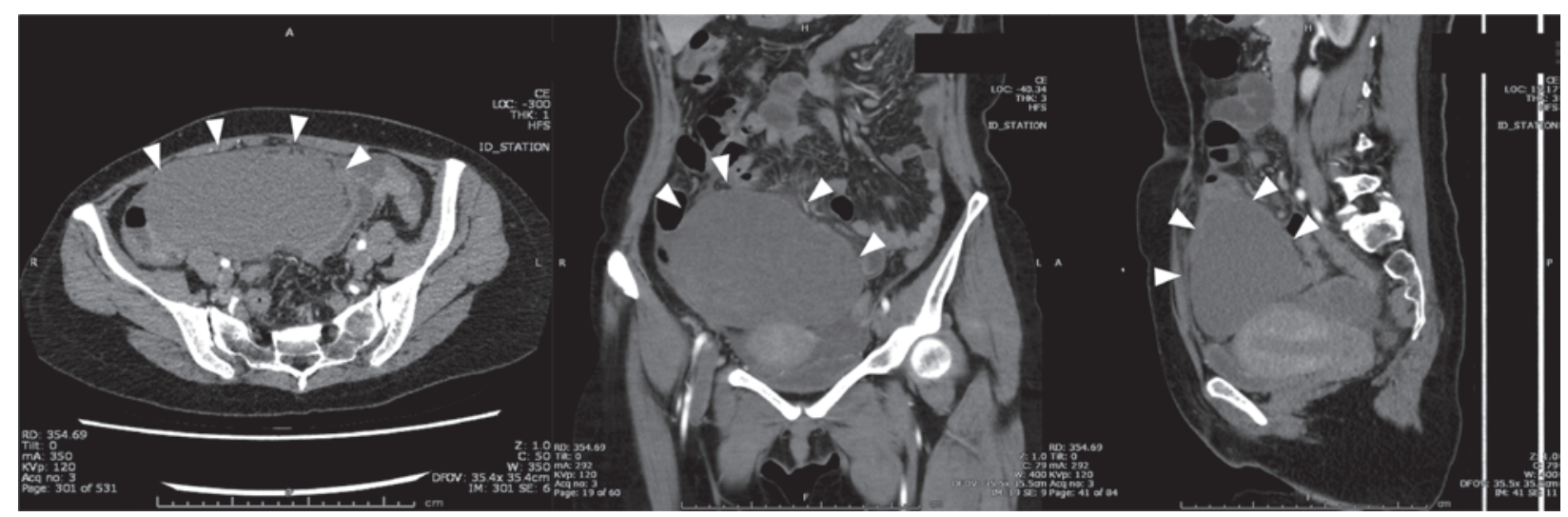

図 1 造影C T検査（水平断、冠状断、矢状断）

右下腹部から臍下に達し子宮底部に接する、造影効果の乏しい最大径 $12 \mathrm{~cm}$ 、辺縁整の内部は均一な囊胞（白矢頭：腹部囊胞）を認める。

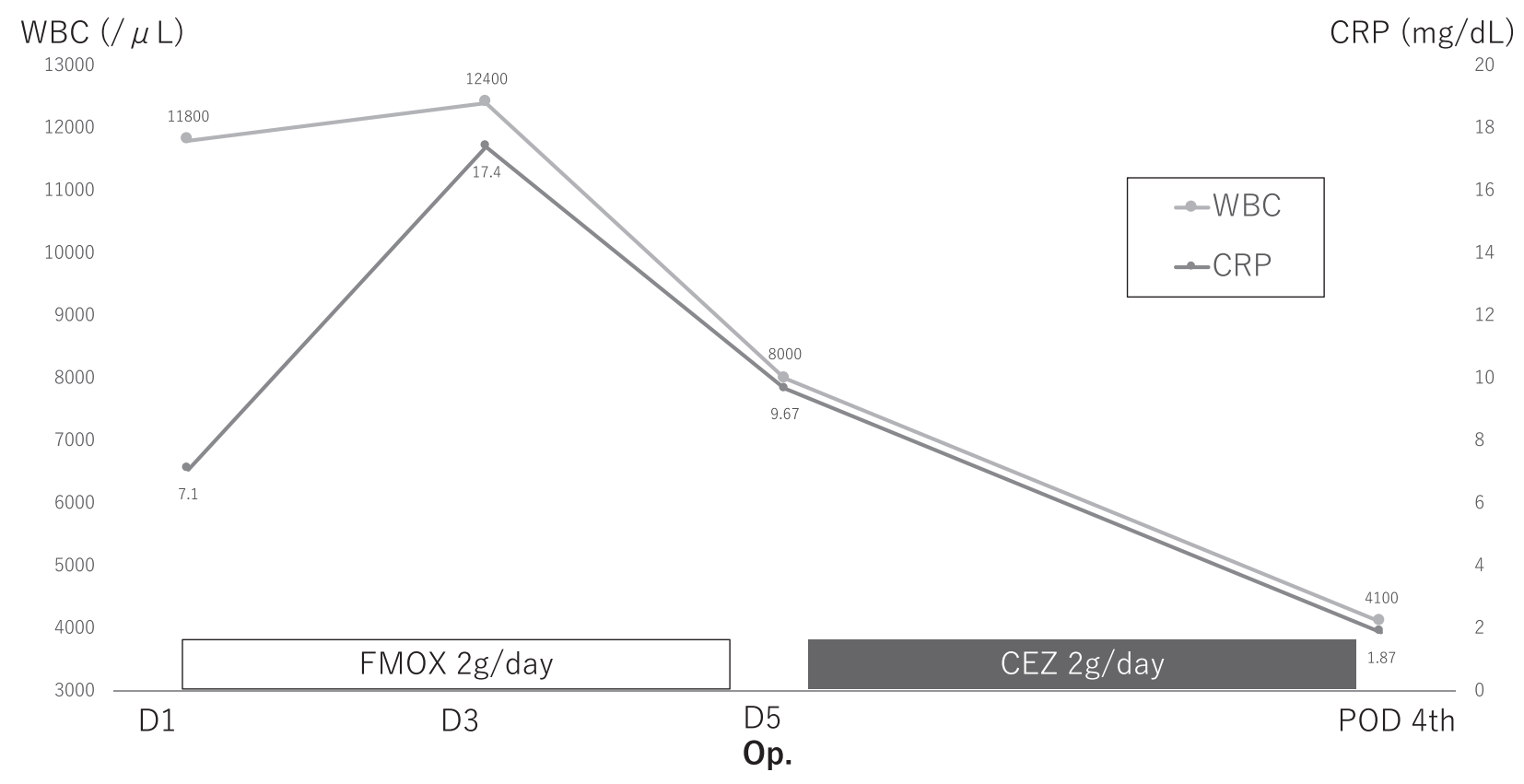

図2炎症所見の経時的変化

左綎軸：WBC $(/ \mu \mathrm{L})$ 、右縦軸：CRP (mg/dl)、横軸：日付 FMOX：フロモキセフ、CEZ：セファゾリン

主訴にかかりつけ内科を受診して経腹超音波検査 で腹部腫瘤を指摘され造影CT検查（図 1 ）と炎 症所見の上昇（図 2 ） から総合病院婦人科に紹介 され、同日入院して骨盤腹膜炎の診断で抗生剂投 与された。感染細菌は同定されなかった。血液検 査でCA125 $=68.4 \mathrm{U} / \mathrm{ml} 、 \mathrm{CA} 19-9=37.9 \mathrm{U} / \mathrm{ml}$ 軽度 上昇あり。入院後のMRI検査（図 3 ) で右卵巣は 正常であり、左卵巣に $5 \mathrm{~cm}$ 大の多房性内膜症性 囊胞を認めた。破裂所見なし。C Tで指摘された 腹部囊胞は子宮卵巣との連続性がそしい腫瘍であ った。手術加療が検討されたが、宗教上の輸血拒 否への対応から当院へ転院した。腸間膜囊胞を鑑 別に消化器外科医立ち合いの下、第 4 病日に腹腔
鏡下に観察・瘾着剥離した。腸管との連続性を認 めず腫瘍摘出術、左付属器切除術を施行した。

\section{手術所見}

術式: 腹腔鏡下腫瘍摘出術および左附属器切除術 手術時間： 1 時間50分 出血量: $100 \mathrm{ml}$ (輸血なし) 手術は全身麻酔下砕石位にて施行した。臍部よ りオープン法にて $5 \mathrm{~mm}$ カラトロッカーを挿入 $\mathrm{LCO}_{2}$ 気腹した (図 4 左)。子宮は正常大(図 $5 \mathrm{~A}$ )、 臍部直下に白色皮膜に覆われた腫瘍を認め、上腹 部から右側腹壁にかけて腹膜や腸管と広く癒着し ていた（図 $5 \mathrm{~B} 〜 \mathrm{D})$ 。臍部を $\mathrm{EZ}$ アクセスに入れ 替え、左側腹部・左上腹部に $5 \mathrm{~mm}$ ポートを設定 

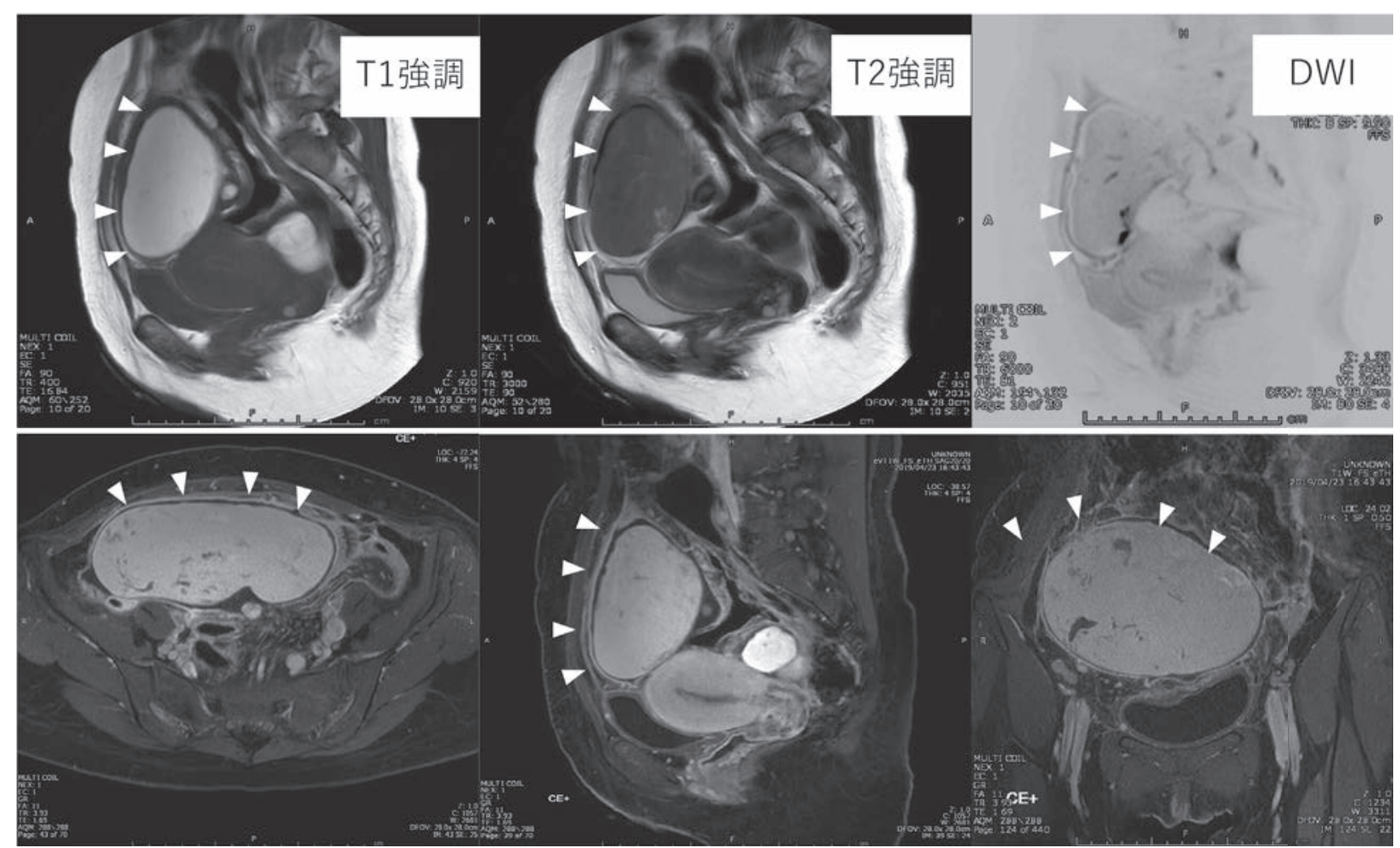

図3 造影M R 検査

上段：矢状断 左よりT1強調 T2強調 DWI 下段：T1強調脂肪抑制造影像 左より水平断 矢状断 冠状断

腹部囊胞（白矢頭）内にはデブリス様像が描出される。腫瘍辺縁は整で、一部拡散能え進を認めるが同部位の造影効果は乏しく、脂肪抑制 で抑制されない。左卵巣腫瘍は多房性でT2 高信号のチョコレート襄胞の所見で充実部分なし。大きさ・位置は2日前のCT所見と变わらない。

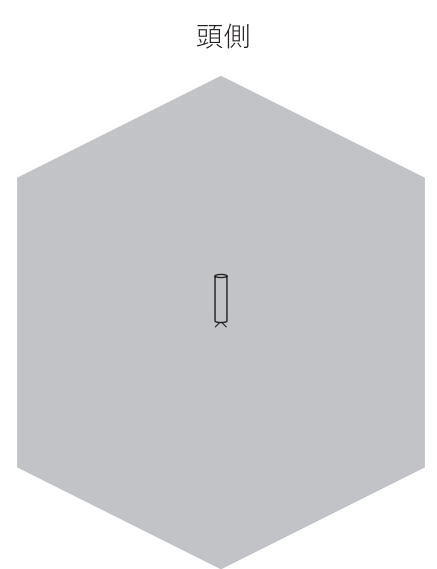

尾側

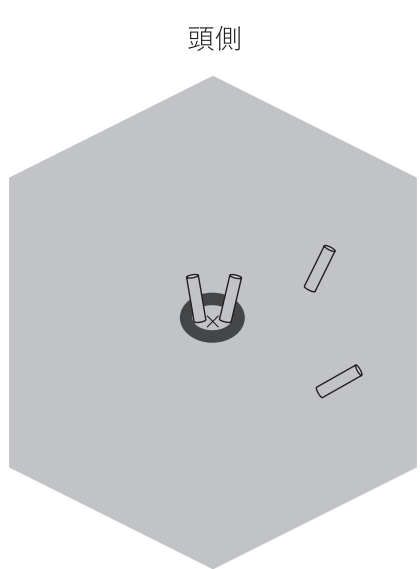

尾側

図4 ポート配置 左) 手術開始時 右) ポート追加後

した（図 4 右)。腹部腫瘤は子宮・卵巣との明ら かな連続性は認めず、観察途中で脆弱な腫瘤被膜 が破綻した。襄胞内容は褐色泥状で約800mlあっ た（図 $5 \mathrm{E})$ 。小腸から虫垂にかけて広範囲の癒 着を剥離したが、囊胞には明らかな血管による連 続性は認めず、孤立性に存在していた。子宮・卵 巣・腸管・腸間膜や大網との連続性も認めなかっ た（図 $5 \mathrm{~F} \cdot \mathrm{G} \cdot \mathrm{I} \cdot \mathrm{K})$ 。右卵巣は子宮背側と癒着
していたが正常大であり、右卵管も異常を認めな かった（図 $5 \mathrm{H}$ )。左卵巣はダグラス窩に嵌頓し、 内膜症性囊胞を含む多房性の腫瘤であったが、左 卵管は正常であった（図 $5 \mathrm{~J}$ )。癒着は容易に剥離 された。囊腫壁は一部に $5 \mathrm{~mm}$ 程度の肥厚を認め た（図 $5 \mathrm{~L}$ )。腹腔内を十分に洗浄し、ドレーン を留置して終了した。 

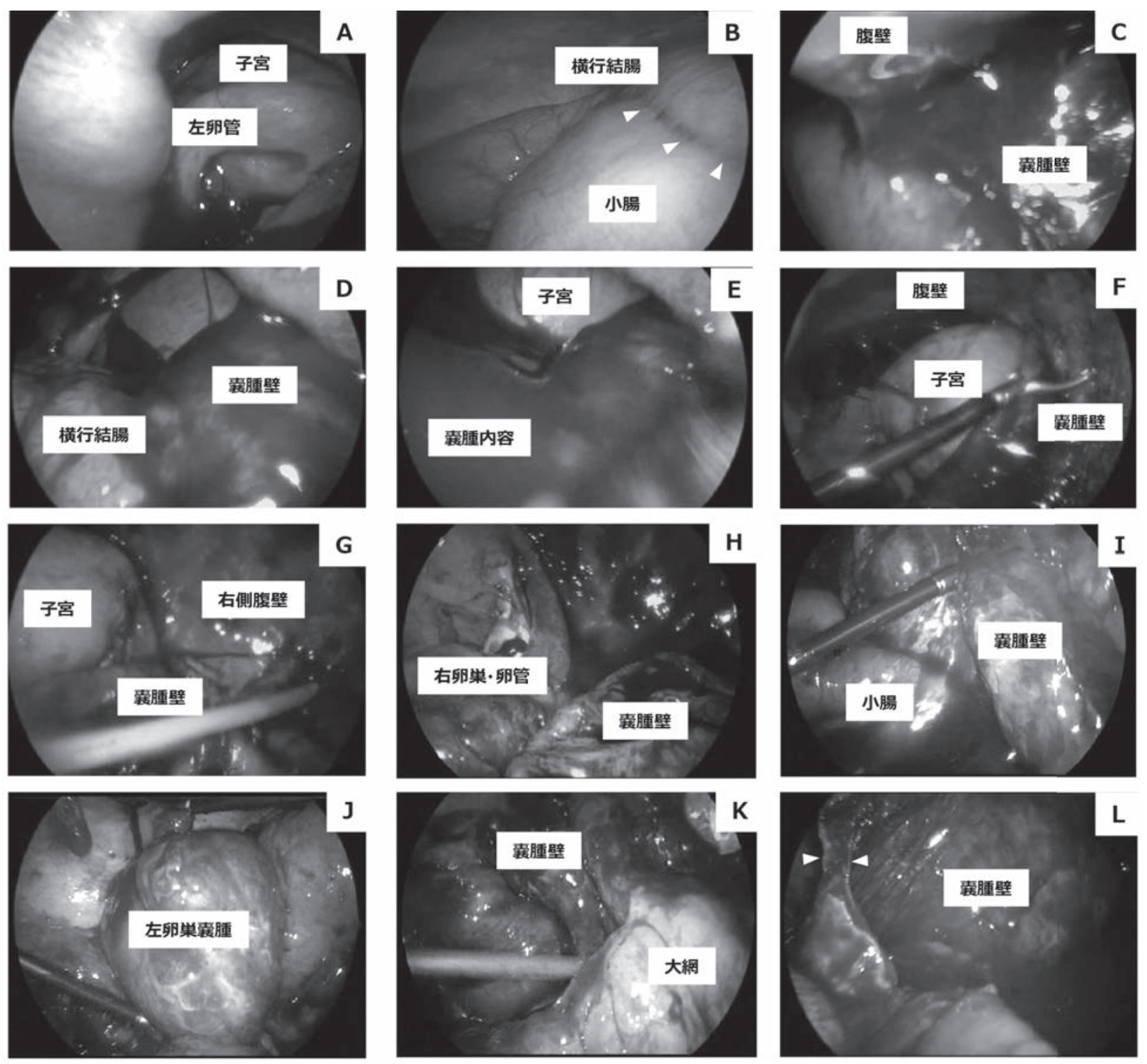

図 5 術中所見
A）左側壁に沿ってカメラを進めると左卵管・子宮が囊胞より尾側に確認できた。
B）襄腫表面は癒着した小腸・横行結腸に覆われていた。
C）臍部直下に白色皮膜に覆われた腫瘍を認めた。腹壁と囊腫壁は癒着し腹腔右側はこの時点では視野が取れなかった。
D）Bの小腸と横行結腸の間の膜状癒着は薄く、辺縁から容易に剥離された。
E）観察中に脆弱な腫瘤被膜が破綻した。内容はチョコレート様で約800mlあった。
F）腹壁から襄腫壁は軽い牽引のみで容易に剥離された。
G）右側壁からも囊腫壁は軽い牽引のみで容易に剥離された。
H）正常大の右卵巣・卵管を確認した。襄腫壁とは牽引のみで容易に剥離された。
I）襄腫壁を挙上して小腸との癒着も牽引のみで容易に剥離された。
J) ダグラス窩の左卵巣囊腫は周囲と癒着しておらず容易に挙上された。
K）大網は囊腫壁と接していたが索状構造無く軽い牽引のみで剥離された。
L）破綻部近傍で囊腫壁は一部で肥厚していたものの白色結節や充実部分は認めなかった。

\section{術後経過}

発熱と腹痛・炎症所見は速やかに改善し、合併 症なく術後 4 日目に退院した。術後療法としてジェ ノゲスト内服を開始した。腹部囊胞の病理所見は 線維性結合織の増生と肉芽組織の形成あり、被覆 する上皮細胞は認めず、へモジデリン貪食とマク
ロファージの集簇あり、P R陽性・E R 弱陽性の 子宮内膜症性囊胞と診断された（図 6 )。

\section{考察}

遊離卵巣囊腫 (wandering cyst, parasitic ovarian cyst, auto-amputated ovarian cyst or acquired 

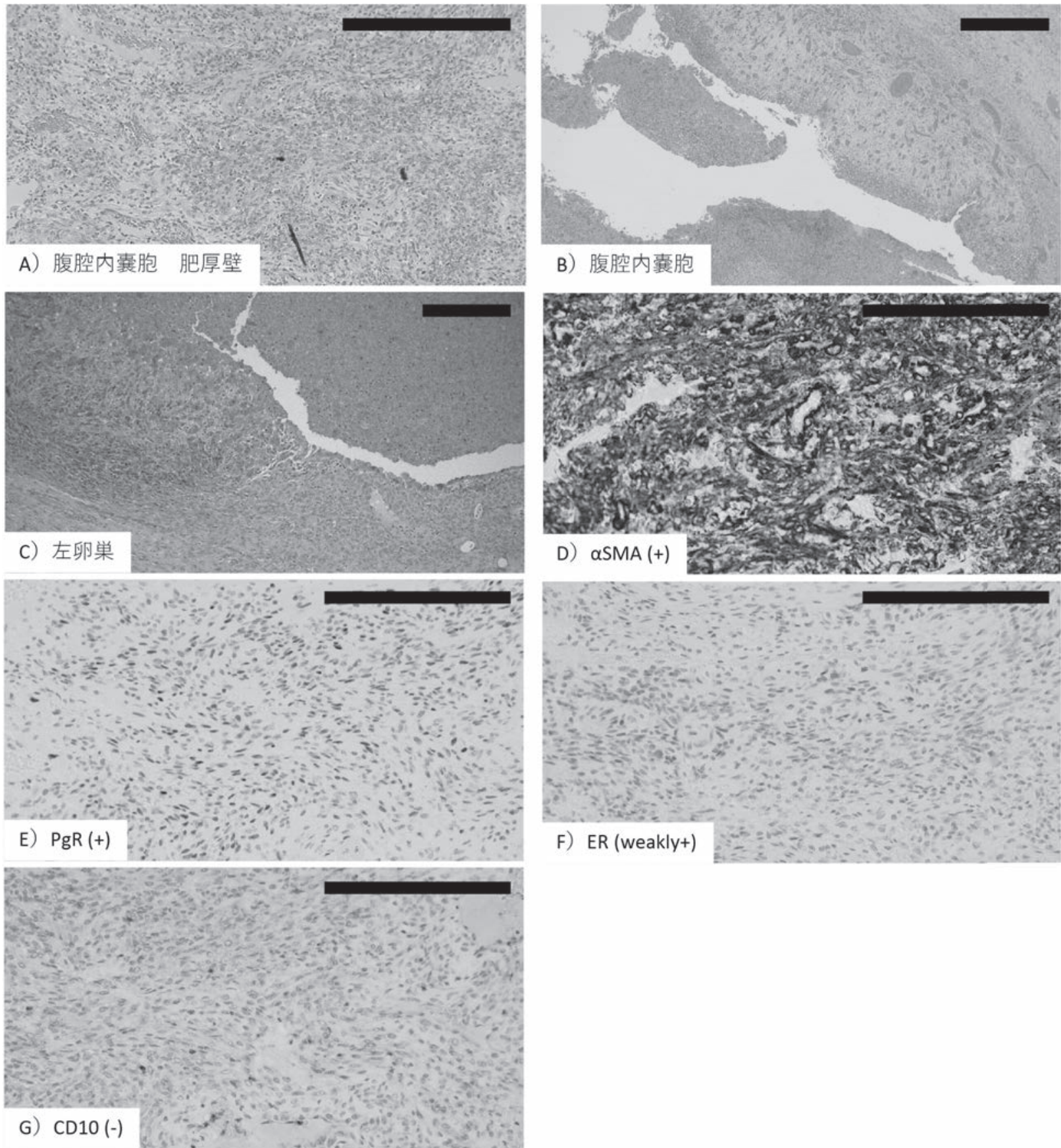

図 6 病理検査

右上のスケールバーは全て100 $\mu \mathrm{m}$ を示す。
A）腹腔内囊胞（肥厚部分）HE染色 $20 \times 100$ 倍。
B）腹腔内囊胞 HE染色 100倍。
線維性結合織の增生と肉芽組織の形成あり、被覆する上皮細胞は認めない。へモジデリン貪食とマクロファージの集簇あり。
C）左卵巣（チョコレート襄胞）HE染色 100倍。ヘモジデリン貪食とマクロファージの集簇あり
D) 腹腔内襄胞 $a$ SMA 陽性 $20 \times 100$ 倍。
E) 腹腔内囊胞 PgR 陽性 $20 \times 100$ 倍。
F) 腹腔内囊胞 $\mathrm{ER}$ 弱く陽性 $20 \times 100$ 倍。
G）腹腔内囊胞 CD10 陰性 $20 \times 100$ 倍。
上記所見よりP R 陽性・E R 弱陽性の子宮内膜症性囊胞と診断した。 
ectopic ovary）は卵巣腫瘍などが茎捻転後に離断 したと考察される稀な病態であり、成人女性での 発症率は婦人科受診患者の $2-70$ 万例に 1 例程度と の報告がある ${ }^{1)}$ 。PubMedでは卵巣線維腫で 1 例 ${ }^{2}$ の他は36例が成熟囊胞性奇形腫で症例報告されて いる ${ }^{3-9)}$ 。医学中央雑誌では会議録として2016年に 塚本らが良性漿液性囊胞で 1 例 ${ }^{10)} 、 2018$ 年に天谷 らはmassive ovarian edemaが遊離腫瘍となった 1 例 $^{11)}$ を報告している。内膜症性囊胞は2015年 に中林らが無症候で診断され腹腔鏡手術した $10 \mathrm{~cm}$ 大囊胞を 1 例 ${ }^{12}$ 報告している。栄養血管は 同定されず腹腔内所見から遊離囊胞と診断され た。本症例のような内膜症病変では遊離卵巣囊腫 としての報告はそしく、周囲との癒着発症のリス クから捻転による遊離は否定的であるとの見方も ある。

他に、卵巣外の子宮内膜性囊胞を呈する病態と してextra ovarian endometrioma（EOE）が報告 されている。EOEの発生部位は腹膜、子宮広間膜、 仙骨子宮勒帯などが多く、術中所見から腫瘤の付 着部位が同定され、囊胞への付着茎や栄養血管が 定義できるものが多く報告されている。高橋ら ${ }^{13)}$ は強固に周囲臓器と瘉着して剥離により腸管漿膜 を欠損した症例・子宮筋腫の合併切除を要した症 例など、 2 症例での周囲臟器の損傷を報告してい る。長尾ら ${ }^{14)}$ は本症例に類似した比較的容易に 剥離された $10 \mathrm{~cm}$ 大囊胞について、右仙骨子宮勒 帯に付着位置を認め、病理所見から卵巣間質構造 を認めず、EOEとして報告している。一方で、 腫瘤の付着部位に関して近年の報告では明示され ないものもあり、福岡ら ${ }^{15)}$ は膀胱子宮窩と大網 にわずかな癒着のみの症例を報告している。遊離 卵巣囊腫とEOEに厳密な分類は困難である。そ の他、卵巣外に子宮内膜症性囊胞が疑われる場合、 既往歴によっては比較的稀な術後Ovarian remnant syndrome（ORS）に発生する子宮内膜 症性囊胞との鑑別も必要である。

本症例は手術既往なく、ORSは否定的である。 腹部囊胞は術中所見で腸間膜を含め周辺臓器と広 沉に膜性に癒着していた。初発疼痛は右側腹部で あったが、右卵巣は正常大であり茎捻転の痕跡は 認めなかった。遊離卵巣内膜症性囊胞に鞟胞内出 血したことにより急性腹症が発症した可能性があ る。一方でEOEの栄養血管が捻転離断して炎症 の原因になった可能性も検討された。囊胞への付 着茎や栄養血管が同定できない点から、本症例で は発症母地が同定できない内膜症性霊胞の遊離卵
巣囊腫と考察した。

囊胞の大きさと炎症所見から術前には開腹手術 の選択肢も検討された。実際にはポート位置に術 中の追加変更を要したものの、腹腔鏡手術による 利点が多かった。腫瘍の大きさと癒着により視野 の確保に難渋したものの、腫瘍全周を詳細に鏡視 下で観察して剥離を進められた。術後回復は順調 であった。重見らにより、重症骨盤内感染症例に おいて、腹腔鏡手術は開腹術に比較して手術時間 が短く輸血が少ないこと、合併症や死亡率の非劣 性が示されている ${ }^{17)}$ 。本症例には輸血制限もあり、 腹腔鏡手術は非常に有用であった。

信仰上の輸血拒否で代表的宗教である「エホバ の証人」の信者は国内で 21 万人と報じられており、 決して稀な事象ではない ${ }^{18)}$ 。救急医療など緊急時 に発覚することで対応に苦慮し診療に遅滞が生じ るリスクも指摘されている。輸血拒否患者への婦 人科腹腔鏡手術について、本邦では松浦らが2012 年に 5 例の腹腔鏡下卵巣腫瘍摘出術について報告 しているが、出血量は少量から $550 \mathrm{ml}$ であり輸血 を要した症例はなかった ${ }^{19)}$ 。出血が想定される腹 腔鏡下子宮筋腫核出術などに関しての婦人科腹腔 鏡患者報告はまだ少ない。輸血や緊急手術は患者 の意思決定に委ねるべきであり、説明を急った医 師には、患者の人権侵害の不法行為責任がある、 との判例もあり、治療方針の選択決定について十 分な情報提供と共に患者の自己決定権に配慮し、 輸血拒否患者への受け入れ体制を各医療機関であ らかじめ明示する必要がある。

\section{結 語}

骨盤腹膜炎を契機に診断された内膜症性の遊離 卵巣囊胞の一例を経験した。他科疾患との鑑別に 苦虑することも多いが、腹腔鏡下手術が診断と治 療に有用と考えられた。

本論文の要旨は第59回日本産科婦人科内視鏡学 会において発表した。

全ての著者は開示すべき利益相反はない。

\section{文献}

1 ) Ushakov FB, et al.: Parasitic ovarian dermoid tumor of the omentum-A review of the literature and report of two new cases. Eur J Obstet Gynecol Reprod Biol. 1998; 81: 77-82.

2) Yazawa H, et al.: An unusual presentation of 
ovarian fibroma originationg from an autoamputated ovary. Gynecol Minim Invasive Ther 2019; 8: 40-43.

投稿日：2020年 1 月 29 日

3 ) John BM.: Ectopic Ovary With Dermoid Cyst as a Result of Possible Asymptomatic Autoamputation. J Hum Reprod Sci. 2017; 10: 226-230.

4) Lee KH, et al.: Autoamputation of an ovarian mature cystic teratoma: a case report and a review of the literature. World J Surg Oncol. 2016; 14: 217.

5 ) Khoo CK, et al.: Parasitic dermoid cyst of the pouch of Douglas: a case report. J Minim Invasive Gynecol 2008; 15: 761-763.

6 ) Hegde P.: Extragonadal omental teratoma: a case report. J Obstet Gynaecol Res. 2014; 40: 618-621.

7 ) Lachman MF, Berman MM: The ectopic ovary. A case report and review of the literature. Arch Pathol Lab Med 1991; 115: 233-235.

8 ) Peh WC, Chu FS, Lorentz TG: Painful right iliac fossa mass caused by a migrating left ovary. Clin Imaging 1994; 18: 199-202.

9 ) Yoshida A, et al.: Case of mature cystic teratoma of the greater omentum misdiagnosed as ovarian cyst. J Obstet Gynaecol Res. 2005; 31: 399-403.

10）塚本早貴, 他:: 腹腔鏡下手術により判明した遊離卵巣 囊腫の一例.日本産科婦人科内視鏡学会雑誌, 2016; 32 suppl: 243.

11）天谷優介, 他.: 妊娠中に発見されたmassive ovarian edemaが産裖期に異所性卵巣となり, 腹腔鏡した手術 を行った一例. 日本産科婦人科学会雑誌. 2018; 70: 1028.

12）中林誠, 他: O-256 術中に判明した無症候の遊離卵巣 腫瘍の一例. 日本産科婦人科内視鏡学会雑誌, $2015 ; 31$ suppl: 208.

13）高橋千波, 他: 診断に苦慮した卵巣外子宮内膜症性囊 胞の2症例. 関東産婦誌 2012; 49: 543-548.

14）福岡佳代, 他: 膀胱子宮窩に孤立性に存在した子宮内 膜症性囊胞の1例. 東京産婦会誌 2014; 63: 234-238.

15）浜口大輔, 他: 膀胱子宮窩腹膜から発生したと考えら れた巨大内膜症性囊胞の1例. 日エンドメトリオーシ ス会誌 2014; 35: 174-178.

16）長尾有佳里, 他: 診断および治療に腹腔鏡下手術が有 用であった卵巣外子宮内膜症性囊胞の一例. 日産婦内 視鏡会誌 2017; 33: 173-177.

17) Shigemi D, et al.: Laparoscopic compared with open surgery for severe pelvic inflammatory disease and tubo-ovarian abscess. Obstet Gynecol. 2019; 133: 1224-1230.

18) J.W.Org. Jehovah's witnesses - religious and ethical position on medical therapy, child care \& related matters. https://www.jw.org/ en/medical-library/ strategies-downloads/religious-and-ethical-positionmedical-therapy/。（最終アクセス日2020年1月11日）

19）松浦祐介, 他：輸血拒否患者に対する婦人科内視鏡手 術の経験. 日産婦内視鏡会誌2012; 28: 465-470. 